\title{
Views of Medical Teachers Regarding Job Satisfaction
}

\author{
Rawshan Ara Khanam ${ }^{1}$, Humayun Kabir Talukder', Tahmina Nargis ${ }^{3}$, M A Wohab Khan ${ }^{4}$, Abdal Mia ${ }^{5}$, \\ S M Idris Ali, Tawhidur Rahman ${ }^{7}$,Wakil Ahmed ${ }^{8}$, Golam Rabbi ${ }^{9}$
}

\section{Abstract \\ Objectives}

To assess the level of job satisfaction among the medical teachers according to their views including existing barriers and ways of further improvement.

\section{Materials and methods}

This was a cross sectional type of descriptive study and was carried out for one year. In depth interview were performed using interview schedule among twenty five medical teachers those were willing to participate in this study and working in preclinical, Para clinical and clinical departments of 5 non government and 5 government medical colleges.

\section{Results:}

In depth interview was conducted among 11 assistant professors, 6 associate and 8 professors . Among them 12 teachers were working in non government and 13 in government medical colleges. Of them 3 teachers were from preclinical ,5 from paraclinical and 17 from clinical departments. Expressed satisfaction level was very low in 5(20\%), low 12 (48\%), moderate $5(20 \%)$, high 2(8\%) and undecided $1(4 \%)$.Good academic environment, good relation with administration, colleagues and students ,job security and location of the institute causes much satisfaction. Main causes of dissatisfaction includes political interference in posting, transfer and promotion of the medical teachers. Low salary, lack of necessary teaching materials. Fifty percent teachers had expressed their dissatisfaction regarding their working place. All of the teachers believed that job satisfaction influences teaching quality and there should be provision for professional development of teachers.

\section{Conclusion}

Job satisfaction among medical teachers is low. There are several causes of satisfaction and so many causes of dissatisfaction . Political consideration in cases of recruitment, posting, transfer and promotion, low salary ,lack of educational materials and educational environment is very important issue for causing dissatisfaction. On job training for professional development of teachers is recommended by all.

\section{Key Words:}

\section{Introduction}

According to Maslow(1954) 'a person's satisfaction is determined by the fulfillment of his five levels of need'. ${ }^{1}$ Job satisfaction defined by Grieshaber et al at 1995 as the positive or negative attitudes held by the individuals toward their jobs ${ }^{2}$.It is a complex function of a number of variables

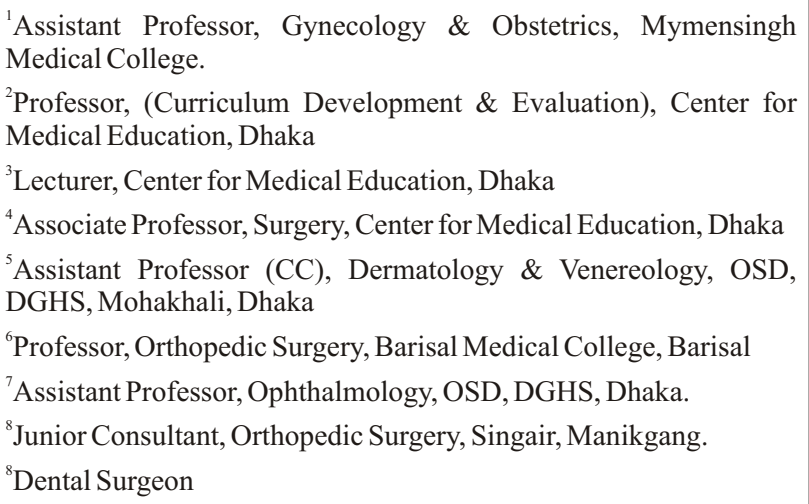

Address of correspondence: Dr.Rawshan Ara Khanam, Assistant Professor, Gynecology \& Obstetrics, Mymensingh Medical College. related to the teachers demographic characters, the work itself, pay, work responsibilities, variety of tasks, promotional opportunities, and relation with co-workers etc. A person may be satisfied with one or more aspects of his/her job but at the same time may be unhappy with other things related to the job ${ }^{3}$. The degree of satisfaction of job is largely depends on satisfaction of these employee variables ${ }^{4}$.Level of job satisfaction can affect both individuals and organization. At the individual level , low level of job satisfaction is a threat to mental and physical health, quality of life , achievement of organizational goal and personal development ${ }^{5}$. Job satisfaction is very important but very less studied issue. Medical teachers job satisfaction decreased dramatically over the past years due to excessive work load, high stress in work area and often loosing career opportunity and ambition. The resulting frustration affects quality of teaching and patient care. It also influences behavior towards co-workers and students ${ }^{6}$. This study was planned to search the answer of the research question- What are the views among medical teachers regarding their job satisfaction? With the objective to find out the views of medical teachers regarding their job satisfaction the study was carried out.

Bangladesh Journal of Medical Education 2011;2(2):18-25. (C) 2011 Ara et al., publisher and licensee Association of Medical Education. This is an Open Access article which permits unrestricted non-commercial use, provided the original work is properly cited. 


\section{Methodology}

This was a cross sectional type of descriptive study and was carried out for one year in preclinical, Para clinical and clinical departments of 5 non government and 5 government medical colleges. In depth interview were performed among 25 teachers those were willing to participate in this study . Sampling technique was convenience sampling. Data collection instrument was interview schedule .Data was presented by detailed description, percentage and verbatim.

\section{Ethical Issues}

There was no ethical problem because all the information has been collected anonymously with prior permission of the authority and all the participants has given their opinion voluntarily. Researcher maintained confidentiality in all cases.

\section{Results}

Among the teachers 11 were Assistant Professor, 6 were Associate Professors and 8 were Professors. The participants were 3 from preclinical, 5 from para clinical and 17 from clinical departments.

The teachers responses on their views regarding medical teachers job satisfaction can be categorized in to two for the purpose of analysis . i) views on the level of satisfaction in general ii) teachers satisfaction regarding their won job.

They has given their opinion on 11 issues which were categorized in to 6 themes as follows: (1). Views regarding level of job satisfaction in general, (2) Views about the factors causing high or low level of job satisfaction of medical teachers, (3). The factors causing satisfaction or dissatisfaction in their work places, (4). Views on how job satisfaction influences quality of teaching, (5). Views regarding the provision for professional development of teachers and the possible methods of professional development of medical teachers. (6). Views regarding the ways for improvement of the current situation.

\section{Views regarding level of job satisfaction in general}

The views of medical teachers regarding job satisfaction in general were as follows - 5 among $25(20 \%)$ believes that, medical teachers has very low level of job satisfaction, 12 among $25(48 \%)$ believes satisfaction is low , 2 among 25 $(8 \%)$ - moderate level of satisfaction, 5 out of $25(20 \%)$ high level of satisfaction and 1 out of $25(4 \%)$ was undecided about the level of satisfaction.

One of the teachers working in public medical college became furious during interview and told " hell with job satisfaction. Write down, job satisfaction is very low in Bangladesh .It is just hopeless."

One paraclinical teacher of a public institute said "as medical teachers are the most neglected teachers in Bangladesh, so the level of job satisfaction is very poor."
One of the teachers working in non government medical college told that, "job satisfaction level is low but it is hidden in mind, no body will speak out with the actual truth."

\section{Views about the factors causing high or low level of job satisfaction among medical teachers}

\section{I) High level of job satisfaction:}

According to the views of the respondents factors influencing the job satisfaction in general were : healthy institutional environment 5(20\%), good administration $5(20 \%)$, good interpersonal relationship $5(20 \%)$, Job security $5(20 \%)$, location of the institute 5(20\%)..

\section{II) Low level of job satisfaction:}

According to the teachers view main cause of dissatisfaction identified by 13 among 25 (42\%) was political interference in recruitment, promotion, posting. Factors identified by 10 among $25(40 \%)$ teachers were lack of support by the administration, interpersonal relationship, low teaching quality, lack of supporting staff, lack of adequate library facilities. Factors identified by 5 out of $25(20 \%)$ teachers were lack of student friendly environment, excessive workload of clinical teachers, lack of collaboration among departments, lack of initiative from the authority, no provision for the further development of teachers.

"Scope of promotion is less and less job security is the cause for low job satisfaction" said one senior level teacher.

One teacher said that," teachers of education cadre and university enjoy different facilities e.g. promotion, upper scales, training in home and abroad but medical teachers don't get any such facilities though they spends much time and give more labor than teachers of other departments."

"Improper way of promotion, no rewards from the higher authority for good work, professional jealousy among colleagues, and political influences are the factors causing dissatisfaction "indicated by one teacher.

" Less promotion opportunity, low salary, dishonesty in promotion and transfer are the causative factors for dissatisfaction " said one teacher working in government medical college.

\section{The factors causing satisfaction or dissatisfaction in work place}

In spite of all short comings 12 out of $25(40 \%)$ teachers were satisfied with their current work place.

I) Factors causing satisfaction in own institute :

According to the medical teachers view factors working behind the job satisfaction in own institute includes good interpersonal relation and handsome salary(in cases of private medical colleges) - told by $6(24 \%)$ teachers, non transferable job( in cases of private medical colleges) and promotion opportunity, location of the institute, respect by the students and also freedom 
of work was the source of satisfaction in $3(12 \%)$ teachers . Good administration was important factor for $3(12 \%)$ teachers. Good team work, good performance of the students and, teaching friendly environment got importance in $1(4 \%)$ teacher.

"Only one aspect of satisfaction is - I have got an opportunity to teach my beloved students though I have so many deprivation from my higher authority" said one teacher with feeling of great frustration.

"As there is no alternative I am satisfied with the job in this institute" said one.

"Job in home district and known environment" is the source of satisfaction for another few.

"Sense of spiritual responsibility only causes satisfaction" this sentence indicates how much frustration is existing among the medical teachers regarding their expectations from the job.

\section{II) Factors causing dissatisfaction in own institute :}

Factors causing dissatisfaction in their own institutes includes- political interference in posting and promotion told by 6 among $25(24 \%)$, less skilled and biased administration 6 out of $25(24 \%)$, student's reluctance for learning 5 out of $25(20 \%)$.

Among many more causes of dissatisfactions the frequently told .causes were - conflict between teacher and administration, non functioning work team, lack of support to the innovative ideas of teaching, lack of teaching materials, lack of IT facilities, and scarcity of supporting staff. Clinical teachers are more dissatisfied as they got less time for preparing classes due to their clinical responsibilities and emergency duties.

" Being senior, proper status is not obtained. Juniors getting more privileges" said one teacher of public medical college with great sorrow.

" Job satisfaction level among medical teachers became intolerable for some senior teachers" said one junior level teacher with much anger and frustration .

\section{Views on how job satisfaction influences quality of teaching}

Most of the teachers believe that job satisfaction influences the quality of teaching by different means .

"A satisfied teacher can spend more and quality time for teaching" were the views of 12 teachers out of 25 (48\%).

" Satisfaction propagates concentration which activates action" were the views of 11 teachers among 25(44\%).

"Teaching friendly environment and availability of necessary teaching materials is very important to create interest" told by 10 teachers out of $25(40 \%)$.

“ Low salary causes less interest for teaching may lead to search for the additional work to maintain the family expenses which interferes with good teaching" was opinion of 6 out of $25(24 \%)$ teachers.

Interpersonal relationship is one of the important issue related to job satisfaction. About 8 out of $25(32 \%)$ teachers views were "Good interpersonal relationship with teachers, authority and students, and as well as social security is importantfor job satisfaction."

"Mental satisfaction enhances motivation which triggers the action" was thought by 8 out of $25(32 \%)$ teachers.

"Unhappiness leads to low drive to teaching and an unsatisfied person can not serve the purpose properly " were the views of 5 out of $25(20 \%)$ teachers.

"If any one has inborn interest for teaching, that teacher will have the creativity and nothing needs for teaching quality "said by one teacher.

"Available and rich library facilities with IT is an important issue for good teaching" was the thought of 5among $25(20 \%)$ teachers.

"Timely promotion, training in home and abroad and independent salary scale can improve the job satisfaction and thus teaching quality" view of 6 out of $25(24 \%)$ teachers.

5. Views regarding the provision and ways for professional development of medical teachers :

All the teachers $25(100) \%$ believes that there must be some provision for the professional development of teachers.

During interview teachers of all levels said that, "Of course, there should be provision for professional development of all level of teachers."

Teachers have some suggestions about the ways and means of professional developments of them. Their views were as follows:

"All teachers must go through the training on teaching methodology" was the opinion of 12 teachers out of 25 $(48 \%)$.

"Frequent and periodic seminar, symposium, workshops on teaching and learning, research methodology etc. may be the alternatives of formal training courses on teaching and learning "suggested by 11 teachers among 25 (44\%).

Some teachers $10(40 \%)$ argued that all formal education needed trained teachers but in complicated teaching like medical education teachers are usually without formal training on teaching which is a strong disparity. So, they recommended that, "medical teachers need - short or long courses on medical education."

"Training on medical education in home and abroad" was also recommended by 9 out of $25(36 \%)$ teachers .

"Visits to the different institutes where medical education 
activities are going on" was the recommendation to improve the teaching method by 9 out of $25(36 \%)$ teachers.

\section{Views about the ways to improve the current situation:}

The views regarding the ways for the improvement of current situation of level of satisfaction of teachers in the educational institutes were, "the factors causing dissatisfaction should be eliminated to improve the level of satisfaction".

"Political interference is the first thing to eliminate from the educational institutes" was recommended by 18 out of $25(72 \%)$ teachers.

"Teachers salary must be handsome" recommended by 12 among 25 (48\%) teachers.

"There should be strict principle to follow for recruitment, posting, promotion and transfer. 'was the opinion of 14 out of $25(56 \%)$ teachers.

"There should be teacher evaluation process which must be fair, followed in all cases and the result should be taken in to account." was the feeling from heart by 15 out of $25(60 \%)$ teachers.

"Administration must be supportive to the teachers and students. "was the view of 15 out of $25(60 \%)$ teachers .

"All concerned persons should be treated equally according to their need " told by 10 among $25(40 \%)$ teachers.

"Feedback must be constructive " recommended by 9 out of $25(36 \%)$ teachers.

"Training on clinical teaching, theoretical teaching, behavior and more interaction between teachers and students ; need to maintain unified standard of examination system in all medical colleges" are also suggested.

\section{Discussion}

Study done in Brazil by Nilce Maria (2009) Showing that factors determining satisfaction and dissatisfaction with the teaching career can be economic, institutional, pedagogical, relational and social ${ }^{7}$. Teaching is seen as pleasurable by a clear majority of teachers ( $57.14 \%$ ). The opinions of the Brazilian teachers were like Bangladeshi teachers and were - ' it is what I like to do most. I earn less, but it's what I enjoy the most' or ' of all the things I do in life, teaching is the most enjoyable thing, the most pleasurable' or ' I am in love with it ' or I enjoy it so much, I can not tell you'. One of the teacher working in a government medical college in Bangladesh said,' I like the job very much as I can teach my beloved students, though I am very much deprived from my higher authority, still 'or as another teacher 'sense of spiritual responsibility only causes satisfaction' and 'if any one has inborn interest for teaching, that teacher will have the creativity and nothing needs for teaching quality.'

During interview 50\% teachers expressed their low level of job satisfaction, some one said job satisfaction as 'hopeless' . They are not only frustrated but very much disappointed with some of the existing systems. Teachers of public sectors were more dissatisfied. It is might because that, in most cases they talked openly but in private medical colleges teachers may not be opened up the actual truth as one said " job satisfaction level is low but it is hidden in mind . No one will speak out the truth'

All teachers believes that job satisfaction influences the teaching quality 'a satisfied teacher can spend more and quality time for teaching'. Study done in Iran by Teamur and Ismaeil (2010) supports this study findings ${ }^{8}$.

All the interviewee teachers believes that,' in the health system there must be some provision for professional development of all level teachers'. The ways may be-long / short course / training on teaching methodology, frequent and periodic seminar, symposium, workshop on teaching and learning and research methodology. Visits of different institutes where medical education activities are going on and training abroad may be the other alternatives. Quality of educational environment has been identified by Reem Abraham et al (2008) as crucial for effective learning which supports the present study'.

For improvement of the current situation of level of satisfaction there were some suggestions. Most important suggestion was to eliminate political intervention. Handsome salary of the teacher creates satisfaction so, salary must be handsome. All the teachers must be evaluated properly and result of evaluation should have utilized. Feed back from the authority must be frequent and constructive. Promotion of the teachers should be on the basis of the result of the teacher evaluation.

\section{Conclusion}

Job satisfaction among medical teachers is below average. Political interference was the most important cause for dissatisfaction. Teachers were in favor of implementing the fair and unbiased policy of recruitment, promotion, posting and teacher evaluation process. There should be some procedure for professional development of medical teachers of all level they recommended.

\section{Recommendations}

From the findings of this study the recommendations are as follows :

1. Teachers salary must be increased. So, the teacher can pay attention to his teaching quality whole heartedly.

2. Political interference is the most important obstacle in relation to administrative aspect, both local and central. This situation needs to change immediately.

3. Facilities of the teachers professional development should be equal for all teacher at a frequent interval . Facilities other than the salary should be increased.

4. Evaluation of teacher and feed back from the authority 
should be maintained properly and regularly. Teachers position should be offered on the basis of teacher evaluation report.

5. All of the teachers must have training or short/long courses on teaching methodology and medical education.

\section{References}

1. Maslow AH 1970, Motivation and Personality, , Harper \& Row publications, New York, p. 35.

2. Grieshaber LD, Parker P, Deering J. Job satisfaction of nursing assistants in long term care. The Health Care Supervisor 1995; 13(4): 18-28.

3. Ghazali SSA, Shah IA, Zaidi SAA, Tahir MH . Job satisfaction among doctors working at teaching hospital of Bahawalpur, Pakistan. J Ayub Med Coll Abbottabad 2007 ;19(3): 42-45.

4. Kumari G \& Pandey KM. Job satisfaction in Public and Private Sector : A Comparison. International Journal of Innovation, Management and Technology $2011 ; 2$ (3): $222-228$.

5. Khuwaja AK, Qureshi R, Andrades M, Fatmi Z, Khuwaja NK. Comparison of job satisfaction and stress among male and female doctors in teaching hospitals of Karachi 2002, retrieve on 3.7.2012 mail: ali.khuwaja@aku.edu

6. Elbashir HMI. Factors influencing medical doctors satisfaction in Khartoum Teaching hospital 2008. Sudanese Journal of Public Health 2009; . 4(2): 310-311.

7. Costa NMSC . Career satisfaction among medical school professors : a case study in Brazil. Rev. bras. Educ. Med. 2009; 33(3) ( http:/ / dx.doi.org/ 10.1590/ so100-55022009000300004 retrieve on 3.7.2012).

8. Aghamolaei T, Fazel I. Medical students' perceptions of the educational environment at an Iranian Medical Sciences University. BMC Medical Education 2010; 10: 87.

9. Abraham R, Ramanarayan K, Vinod P, Torke S 2008, Students' perceptions of learning environment in an Indian medical school, no.8, pp.20-9 http: //www. Biomedcentral.com/1472-6920/8/20.

\section{References}

Abraham R, Ramanarayan K, Vinod P, Torke S 2008, Students' perceptions of learning environment in an Indian medical school, no.8, pp.20-9 http://www. Biomedcentral.com/1472-6920/8/20.

Aghamolaei T, Fazell 2010, Medical students' perceptions of the educational environment at an Iranian Medical Sciences University, BMC Medical Education, no.10, pp. 87.

Ashton PT, Webb RB 1986, Making a difference: teachers' sense of efficacy and student achievement, New York : Longmann.

Bell DJ ,Bringman J, Bush A, Phillips OP 2006 , Job satisfaction among obstetricians-gynaecologists: a comparison between private physicians and academic physicians, AMJ Obstet Gynecol. vol. 195, pp. 1474- 8.

Bell RC, \& Weaver JR 1987, The dimensionality and scaling of job satisfaction : an internal validation of worker opinion survey, Journal of occupational Psychology, vol. 60, pp. 147-155.

Boe EE, \& Gilford DM 1992, Teacher supply, demand and quality, National Research council, National Academy press, Washington, DC.

Castle NG 2006, An instrument to measure job satisfaction of nursing home administrators, BMC Medical Research Methodology, vol.6, no.47, pp.1-11. ttp:/ h/www.biomedcentral.com/1471-2288/6/47.

Chacko TI 1983, Job and life satisfaction: A causal analysis of their relationship, Academy of management Journal, vol.26, pp. 163-69.

Charles O O, Mukaila AS, Bukola OO, Dantonjo EA 2010 ,Libyan J Med, no. 5 , pp. 4629-DOI: 10.4.176/091010 (reativecommons.org).

Cherniss C \& Kane JS 1987, Public sector professional: job characteristics, satisfaction, and aspirations for intrinsic fulfillment through work, Human Relations, vol. 40, pp. 125-136.

Choy SP, Bobbit SA, Henke RR, Medrich EA, Horn LJ, Lieberman J 1993, America's Teachers: Profile of a Profession, U. S. Department of Education, Office of Educational Research and Improvement, National Centre for Education Statistics, Washington, DC.

Clark AE 1998, Measures of job satisfaction - what makes a good job? Evidence from OECD countries, Labour market and Social policy - occasional paper no. 34, OECD, Paris.

Costa NMSC 2009, Career satisfaction among medical school professors : a case study in Brazil, Rev. bras. Educ. Med.vol. 33, no. 3( http:/ / dx.doi.org/ 10.1590/ so10055022009000300004 retrieve on 3.7.2012).

Cross D 1973, The worker opinion survey : A measure of shop-floor satisfaction, Occupational psychology, vol. 47, pp. 193-208.

David M \& Burgess J F Jr. 2011 , Job Characteristics and Job Satisfaction Among Physicians Involved with research in the Veterans health Administration, Academic Medicine, vol.86, no.8, pp. 938-45.

Diaz- Serrano \& Cabral Vieira JA 2005, Low pay, higher pay, and job satisfaction within the European Union: Empirical evidence from fourteen countries, IZA discussion Papers No.1558, Institute for the study of Labor. 
Donald E, William E, Thomas R, Eric S, Linzer M, Douglas J 2002, Physician job satisfaction, dissatisfaction, and physician turnover, The Journal of Family Practice, vol.51, no.7,pp. $51-6$.

Elbashir HMI 2009, factors influencing medical doctors satisfaction in Khartoum Teaching hospital 2008, Sudanese Journal of Public Health, vol.4, no.2,, pp. 310-311.

Ferguson K, Frost L, Hall D 2012, Predicting Teacher Anxiety, Depression, and job Satisfaction, Journal of Teaching and Learning, vol. 8 , no. 1, pp. 27-41.

Filak VF \& Sheldon KM 2003, Student Psychological Need Satisfaction and College Teacher Course Evaluations, Educational Psychology, vol.23, no.3, pp. 235-247.

French F, Ikenwilo D, Scott A 2007, What influences the job satisfaction of staff and associate specialist hospital doctors?, Health Serv Manage Res, vol.2, no.3, pp. 153161.

Ghazali SSA, Shah IA, Zaidi SAA, Tahir MH 2007, Job satisfaction among doctors working at teaching hospital of Bahawalpur, Pakistan, J Ayub Med Coll Abbottabad, vol. 19, no. 3, pp. 42-45.

Gorth H, Koster AD, Storz P,Nolting HD, Haussler B 2007, Job Satisfaction among doctors ,DTSCH ARZTEBL, vol.104, no. 20, pp.1394-9.

Grieshaber LD, Parker P, Deering J 1995. Job satisfaction of nursing assistants in long term care. The Health Care Supervisor, vol.13, no.4,pp. 18-28

Gupta R, Vohra AK, Gupta A Singla SL 2002, A Study of Hostility, Career choice and Job Satisfaction Among Surgeons, MJAFI, no. 58, pp. 210-13.

Harzberg F, Mausner B, Snyderman BB 1959, The Motivation of Works, $2^{\text {nd }}$ Edition. New York, John Wily and Sons.

Herzberg, Frederick 1968, Work and the nature of man, London: Saples Press.

Hoppock R 1935, Job Satisfaction, pp. 22, Harper, New York.

Hoy W K ,Miskel CG 1978, Educational administration: Theory, Research and Practice, New York, Random House.

Hoy, Wayne, Miskel, Cecil 1996, Educational Administration: Theory, research and Practice, 5 th edition, New York, Mc Graw-Hill.

Hulin CL, Smith PC 1964, Sex differences in job satisfaction, Journal of Applied Psychology, vol. 48, pp. 8892.

Ironson GH, Smith PC, Brannick MT, Gibson WM, Paul KB 1989, Construction of a job in General Scale : a comparison of global , composite, and specific measures, J
Appl Psychol, vol. 74, pp.193-200.

Janus K, Amelung VE, Baker LC, Gaitanides M, Schwartz FW, Rundall TG 2008, Job Satisfaction and Motivation among Physicians in Academic Medical Centers: Insights from a Cross - national Study, Journal of Health Politics, Policy and Law, vol. 33, no. 6, pp. 1133-67.

Jennet PA, Kishinevsky M, Bryant H, Hunter KL 1990, Major changes in medical careers following medical school graduation : When ,how often and why, Acad Med vol.65, pp. 48-9.

Job satisfaction among America's teachers: effects of workplace conditions, background characteristics and teacher compensation, July 1997, statistical analysis report, Washington D.C.

Judge TA, Thoresen CJ, Bono JE, Patton GK 2001, The job satisfaction - job performance relationship : a qualitative and quantitative review. Psychological Bulletin,vol. 127 no.3, pp. 376-407.

Johnson SM 1990, Teachers at work, Basic Books, New York.

Khaleque A, \& Rahman MA 1991, Perceived importance of job facets and overall job satisfaction of industrial workers, Human Relations, no. 40, pp. 401-16.

Khuwaja AK, Qureshi R, Andrades M, Fatmi Z, Khuwaja NK 2002, Comparison of job satisfaction and stress among male and female doctors in teaching hospitals of Karachi, retrieve on 3.7.2012 mail: ali.khuwaja@aku.edu

Kumari G \& Pandey KM 2011, Job satisfaction in Public and Private Sector: A Comparison, International Journal of Innovation, Management and Technology, vol. 2, no. 3, pp. $222-228$.

Kyriacou C 2001, teacher stress: Directions for future research, Educational reniew, vol.53, vol.1, pp.27-35.

Landon BE, Aseltine R, Shaw JA et al 2002, Evolving dissatisfaction among primary care physicians, Am J Managed Care, vol.8, pp. 890-901.

Lawler E \& Suttle J 1972, A causal correlation test of need hierarchy concept, Organizational Behavior and Human Performance, pp. 265-287.

Leigh JP, Kravitz RL, Schembri M, Samuels SJ, Mobley S 2002, Physician career satisfaction across specialists, Arch Intern Med, vol. 162, pp. 1577-84.

Lewis PS, Goodman SH, Fandt PM 1995, Management: Challenges in the $21^{\text {st }}$ Century, West Publishing Company, New York.

Linn LS, Yager J, Cope D, Leake B 1986, Factor associated with life satisfaction among practicing internists, Med Care, vol. 24, pp. 830-37. 
Locke EA 1976, The nature and causes of job satisfaction, hand book of industrial and organizational psychology, Chicago, Rand McNally.

Linn LS, brook RH, Clark VA Davies AR, Fink A, Kosecoff J 1985, Physician and patient satisfaction of factors related to the organization of medicine group practices, Med care, no. 23 , pp. 1171-8.

Macdonald S \& MacIntyre P 1997, the Generic Job Satisfaction Scale: Scale development and its correlates, The Haworth Document delivery Service: 1-800-342-9678.

Machaelowa K, Wittmann E 1999, Teacher job satisfaction , student achievement and the cost of primary educationevidence from francophone Sub-Saharan Africa, COFEMEN,E-mail : pasec@,sentoo.sn

Madan N, Job satisfaction among Doctors in a Tertiary Care Hospital 2008, JK science, vol.10, no.2, pp. 81-83.

Martha SG, Lisa MW, Skochelak E 1997, Job Satisfaction of medical Teachers and teaching Quality, J Gen Intern med. vol.12, no.S2, pp.90-97.

Maslow AH 1970, Motivation and Personality, New York, Harper \& Row.

Mawardi BH 1979, Satisfaction, dissatisfactions, and causes of stress in medical practice, JAMA, vol. 241, pp. 1483-6.

Medical Council of India 1992, Proceedings of the National Workshop on need based curriculum for graduate medical education, pp.28-9.

Menlo A, Poppleton P 1990, A Five Country Study of the Work Perceptions of secondary School Teachers in England, the United States ,Japan, Singapore and West Germany (1986-1988) . Comparative Education, vol.26, no.2-3, pp. 173-182.

Nabi SR 1995, The Impact of an Educational Innovation on Students' Performance, Classroom practice and Teachers Behaviors in Chitral, Pakistan, unpublished phD thesis, University of Bristol, Bristol

Novoa A 1997 , Formacao de professores e profissao, Os professors e sua formacao, Lisboa: Publicacoes Dom Quixote, pp. 15-33.

Nylenna M, Gulbrandsen P, Forde R, Aasland OG 2005, job satisfaction among Norwegian general practitioners, Scandinavian Journal of Primary Health Care, no. 23, pp. 198-202.

Ostroff C 1992, the relationship between satisfaction, attitude and performance : an organizational level analysis, Journal of Applied Psychology, vol. 32, pp. 963-74.

Ramanathan CS 1991, Stress and job satisfaction : Implications for occupational social work, Employee Assistance Quarterly, vol.6, no. 2, pp. 31-39.
Rose M 2003, good deal, bad deal? Job satisfaction in occupations, vol. 17, no.3, pp. 503-530.

Rosta J, Nylenna M, Aasland OG 2009, Job satisfaction among hospital doctors in Norway and Germany. A comparative study on national Samples, Scandinavian journal of public health, vol. 37, no. 5, pp. 503-508.

Rout U, Cooper CL, Rout JK 1996, Job Stress Among British General Practitioners: Predictors of job Dissatisfaction and Mental Ill Health, Stress Medicine, vol.12, pp. 155-166.

Rout U, Rout JK 2006, A comparative study on occupational stress, job satisfaction and mental health in British general practitioners and Canadian family physicians, Psychology, Health \& Medicine, vol.2, no.2, pp. 181-85.

Saanee NV, Sluiter JK, Verbeek HAM, Frings- Dresen MHW 2003, Reliability and Validity of Instruments measuring Job Satisfaction - a systematic review. Occupational Medicine, vol.53, pp. 191-2000.

Saiyadain M 2007, Human resource management, New Delhi, Tata Mc Graw Hill.

Scarpello V, \& Campbell JP 1983, Job satisfaction: Are all the parts there?, Personnel Psychology, vol.36, pp. 577600 .

Shidhaye RV, Divakar DS, Gaurav G, Shidhaye R 2011, Anaesth pain \& Intensive Care, vol. 15, no. 1 pp. 30-37.

Smith PC, Hulin CL, Kendal LM, Locke EA 1974 , The development of a method of job satisfaction : The Cornell studies . In studies in personnel and industrial psychology $3^{\text {rd }}$ edition. Edited by: Fleishman EA, Bass AR. Homewood, IL: Dorsey Press.

Somech, Anita, Dranch - Zahavy, Anat 200, Understanding extra - role behavior in schools: the relationships between job satisfaction, sense of efficacy, and teachers 'extra-role behavior, Teaching and Teacher Education, vol. 16, pp. 64959 .

Sousa- Poza A, \& Sousa -Poza AA 2000, Well -being at work: A cross national analysis of the levels and determinants of job satisfaction, Journal of SocioEconomics, vol. 29, no. 6, pp. 517-538.

Spector PE 1997, Job satisfaction: Application, assessment, causes, and consequences, Sage. London.

Suryanarayana NVS \& Luciana MZ 2010, Teaching competency and teacher job satisfaction among secondary school teachers, www. teacher learner.com.

Whawo DD 1993, Educational Administration: Planning and Supervision, Benin city, Judah Publication.

Yeasmin A, Abdulghafour, Anwar M, Bo-hamra, Moneera S, Al-Randi, Mohamed I, Kamel, Medhat k, El- Shazly 
2011, Burn out syndrome among physicians working in primary health care centers in Kuwait, Alexandria Journal of Medicine, vol.47, no. 4, pp. 351-357.

Zabalza M A 2004, O ensino universitario: seu cenario e protagonistas, Sao Paulo: Artmed, pp. 239.
Zuger A 2004, Dissatisfaction with medical practice, NEJM, vol. 350, pp. 69-75. 